\title{
Correction to: Complementary feeding methods in the first year of life: a study protocol for a randomized clinical trial
}

Leandro Meirelles Nunes ${ }^{1,2}$, Jordana Führ ${ }^{1}$, Christy Hannah Sanini Belin ${ }^{1}$, Paula Ruffoni Moreira ${ }^{3}$,

Renata Oliveira Neves ${ }^{1 *}$, Mariana Lopes de Brito ${ }^{1}$, Lorenzo Andreazza Morando ${ }^{4}$, Adriela Azevedo Souza Mariath ${ }^{4}$, Erissandra Gomes ${ }^{4}$ and Juliana Rombaldi Bernardi ${ }^{1,3,5}$

\section{Correction to: Nunes (2021).}

https://doi.org/10.1186/s13063-021-05647-1

Following the publication of the original article [1], we were notified that the wrong birth weight was introduced during Production: $3.500 \mathrm{~g}$ (incorrect) instead of $2.500 \mathrm{~g}$ (correct).

The original article has been corrected.

\begin{abstract}
Author details
'Graduate Program in Child and Adolescent Health, Universidade Federal do Rio Grande do Sul (UFRGS) Medical School, Porto Alegre, Brazil.

${ }^{2}$ Neonatology Section, Hospital de Clínicas de Porto Alegre (HCPA), Porto Alegre, Brazil. ${ }^{3}$ Graduate Program in Food, Nutrition and Health, Universidade Federal do Rio Grande do Sul (UFRGS) Nutrition Department, Medical School, Porto Alegre, Brazil. ${ }^{4}$ Department of Surgery and Orthopedics, Universidade Federal do Rio Grande do Sul (UFRGS) Dentistry School, Porto Alegre, Brazil. ${ }^{5}$ Nutrition Department, Universidade Federal do Rio Grande do Sul (UFRGS), Hospital de Clínicas de Porto Alegre (HCPA), Porto Alegre, Brazil.
\end{abstract}

Published online: 18 November 2021

\section{Reference}

1. Nunes et al. (2021) Complementary feeding methods in the first year of life: a study protocol for a randomized clinical trial (2021) 22:687 DOI: https:// doi.org/10.1186/s13063-021-05647-1

The original article can be found online at https://doi.org/10.1186/s13063021-05647-1.

* Correspondence: renataoliveiraneves@gmail.com

${ }^{1}$ Graduate Program in Child and Adolescent Health, Universidade Federal do Rio Grande do Sul (UFRGS) Medical School, Porto Alegre, Brazil

Full list of author information is available at the end of the article

(c) The Author(s). 2021 Open Access This article is licensed under a Creative Commons Attribution 4.0 International License, which permits use, sharing, adaptation, distribution and reproduction in any medium or format, as long as you give appropriate credit to the original author(s) and the source, provide a link to the Creative Commons licence, and indicate if changes were made. The images or other third party material in this article are included in the article's Creative Commons licence, unless indicated otherwise in a credit line to the material. If material is not included in the article's Creative Commons licence and your intended use is not permitted by statutory regulation or exceeds the permitted use, you will need to obtain permission directly from the copyright holder. To view a copy of this licence, visit http://creativecommons.org/licenses/by/4.0/ The Creative Commons Public Domain Dedication waiver (http://creativecommons.org/publicdomain/zero/1.0/) applies to the data made available in this article, unless otherwise stated in a credit line to the data. 